\title{
On the Railway Freight Transport in China
}

\author{
NOJIRI Wataru* and JIANG $\mathrm{Xu}^{* *}$ \\ * Faculty of Economics, Momoyama Gakuin University, Osaka 594-1198, Japan \\ ** Post-Doctoral Researcher, Graduate School of Economics, \\ Momoyama Gakuin University, Osaka 594-1198, Japan
}

\begin{abstract}
Various statistical analyses were conducted to determine the relationship between economic indicators for Chinese provinces and railway freight volume. The results indicated that southeastern coastal areas such as Shanghai and Guangzhou received foreign capital and experienced rapid economic growth in secondary and tertiary industries. On the one hand, railway freight transport is centered on coal production regions like Dongbei and Huabei. In addition, a cluster analysis was performed on the distribution ratio classified by destination province for the railway freight volume from each province. The results indicate that China as a whole can be divided into seven railway freight transport zones such that the freight distribution ratios for destination provinces are similar for neighboring provinces.
\end{abstract}

Key words: railway freight transport, coal, cluster analysis, transport zone, China

\section{Introduction}

Along with the remarkable economic growth achieved in recent years, modernization of logistics seems to be rapidly progressing in China. However, it is difficult to say that statistics on China's logistics are sufficiently complete. For statistics on freight volumes between regions, only railway statistics are aggregated and published. Thus in this paper, with these statistics as fundamental data, we want to clarify the regional structure of China's railway freight transport.

One of the most interesting research topics in geography is the analysis of spatial structure for freight transport. Ullman (1957), Knudsen (1985), Berry (1966), Wallace (1967), Mitsuhashi (1978), Kanno (1976), Murayama (1984, 1990), and Han (1981) have already elucidated the spatial structure for freight transport for various nations. These studies obtained figures in the form of detailed origin-destination matrices for various industrial sectors and freight types, and also obtained splendid analytical results through trial applications of spatial interaction models and multivariate analysis.

However, there has been a lag in the prepara- tion of statistics on regional economy, transportation, and goods distribution in response to recent rapid economic development in China. For example, there are no statistics on interregional automobile-based freight transport. As for water-based transportation, origin-destination matrices differentiated by article transported, have not been tabulated. The only statistics on inter-regional freight transport volume published and obtainable for China are in the annually published Year Book of China Transportation and Communications (Year Book House of China Transportation and Communications 2004). The book consists solely of inter-regional freight transport volume statistics (origin-destination matrices) for the China National Railway.

The present study, then, seeks to analyze the current state of Chinese railway freight transport, focusing on origin-destination matrices. The available data differs from that of Japan and Europe or America in that it is not possible to obtain transportation volume figures categorized by industry sector or freight article. Accordingly, it is not possible to analyze trends for production sites or regional economies, as was done in the above-mentioned studies. In this respect, the present study is inadequate. Moreover, given that the analysis addresses the national railway alone, 
this study is not able to elucidate the characteristics of China's overall distribution of goods.

However, even today the railway system accounts for a high percentage of the overall domestic distribution of goods in China. Moreover, China has the largest railway freight transport volume in the world. According to the China Railway Yearbook 2002, published by Ministry of Railway (2002), China led first in terms of the volume of railway freight transport logged in 2001. China recorded 1.93 billion tons through the Chinese national railway alone, surpassing the United States' figure of 1.6 billion tons and Russia's 1 billion tons. This is why clarifying the state of affairs for China's railway freight transport is highly significant for geographical research.

Furthermore, there is a limit to the tabulated statistical data that is published and obtainable on China's regional economy and distribution of goods. In addition, there generally tends to be a considerable regional bias in the statistical data, making them incompatible with correlation, regression, or multivariate analyses. For that reason, it is difficult to detect a sufficiently clear relation between railway freight volume and the corresponding statistical data. Accordingly, it is not possible to clearly elucidate the extent to which regional economic state of affairs influences railway freight transport. However, this study hopes to use the above data as a basis for portraying railway freight transport conditions in terms of descriptive statistics.

Due to these kinds of constraints on the data, sufficient computational analysis was not possible in this paper. However, for the methodology in this paper, we want to refer Starr, Jr. (1976), which has railway transport in the USA as its subject. His research clarified coupling relationships between regions based on large volume transport of trainloads such as coal, grain, etc. In this paper, we want also to proceed with research while focusing on large volume transport of coal on China's railways.

\section{China's Regional Economic Outlook and Logistics}

\section{Economic growth and infrastructure development}

China's economic and development policies until the 1970s centered on agricultural production and increased food production, based on domestic self-sufficiency. Development in rural areas was prioritized, with the goals of fairness across regions and even development. Since the 1980s however, large policy changes have been made to develop industry, steadily opening the market to foreign companies (Yang 1990). That trend became even stronger in the 1990s.

This development investment policy of China favored certain regions, centering on the southeast coastal region in particular. Linking the coastal region to the international market economy was prioritized, based on easing various regulatory policies. It focused on increased investment of foreign companies and higher per capita GDP. Production of labor intensive textiles, consumer electrical products, and electronics products concentrated in the southeast coastal region. In other words, China's development investment policy underwent a large change, towards prioritizing development of specific regions, centering on large cities and industrial regions (Fan 1995; Fan and Scott 2003).

As a result, beginning with the 1990s, regional economic disparities increased even more between cities and rural areas, and between coastal and internal regions. Thus it became necessary to eliminate regional imbalances by further expansion of this regulatory easing and economic liberalization in inland regions. In particular, improvement of the transport infrastructure became even more important for overcoming geographic obstacles to increase economic growth in the internal western regions. These measures are also necessary for China to overcome its uneven distribution of energy resources such as coal and petroleum, and to develop industries nationally (Hoyle et al. 1998; Démurger 2001; Démurger et al. 2001).

However, the following problems have been identified, especially regarding infrastructure re- 
lated to distribution. Transportation administration is divided, and there is little cooperation between each administration, so construction of inter-modal transportation and distribution systems is lagging. There is also lack of improvements in transportation services and unique policies and regulations of local governments are becoming an obstacle to wide inter-regional distribution (Ka 2005).

\section{Economic indicators for each region and logistics}

In China, the China Statistical Yearbook (National Bureau of Statistics of China 2004) provides figures on various economic indicators by province. A cross tabulation was performed for the 2003 data. Comparing foreign investment expenditure figures relative to the entire nation (excluding Hong Kong and Macao), one finds that expenditure was concentrated in Jiangsu (19.0\%), Guangdong (18.9\%), Shandong $(10.9 \%)$, Shanghai $(9.8 \%)$, and Zhejiang (9.0\%). In other words, the introduction of foreign capital was concentrated in the lower reaches of the Changjiang River and the Zhujiang River.

Moreover, looking at 2003 GDP totals for each province (regional net production or Gross Regional Production) relative to the entire nation (excluding Hong Kong and Macao), one finds that it was concentrated in Guangdong (10.5\%), Shandong (9.2\%), Jiangsu (9.2\%), and Zhejiang (6.9\%). Out of those numbers, one finds that the figures for primary industry GDP are concentrated in Sichuan (8.0\%), Shandong (7.5\%) Henan (6.3\%), Jiangsu (5.6\%), and Hebei (5.4\%). For secondary industry GDP, the figures are Guangdong (10.8\%), Jiangsu (9.6\%), Shandong (9.4\%), and Zhejiang (7.0\%). For tertiary industry GDP figures, the order was Guangdong (12.2\%), Jiangsu (10.1\%), Shandong (9.6\%), and Zhejiang $(8.3 \%)$. With the exception of Sichuan's primary industry GDP figures, the southeastern coastal region has a large share of China's economic activity.

Now let us look at the province-by-province percentages of outgoing and incoming railway freight volume relative to the nation as a whole (excluding Hong Kong and Macao). Outgoing volume was concentrated in Shanxi (18.4\%), Heilongjiang (7.0\%), Liaoning (6.6\%), Shandong
(6.5\%), Hebei (6.4\%), and Henan (6.0\%). Incoming freight was concentrated in Hebei $(12.6 \%)$, Liaoning $(9.3 \%)$, and Shandong (7.2\%). Figure 1 shows that the railway freight transport volume is concentrated in the north of China.

A correlation analysis was conducted for various kinds of regional economic data in 2003, and Table 1 shows results that were proved to be significant. As the table shows, secondary GDP, tertiary GDP, and foreign investment expenditure exhibit a strong correlation. There is also a weak correlation between primary, secondary, and tertiary GDP and incoming railway freight volume. These figures can be tentatively said to reflect the fact that incoming freight volume is greater in regions with prosperous economic activity. Meanwhile, railway freight shipping volume shows a strong correlation with coal production volume.

Next, the changes from 1985 to 2003 in railway freight outgoing and incoming volume in each province are analyzed, setting 1985 figures as a baseline of 100. Figure 2 shows the distribution of changes in each province for the outgoing and incoming railway freight volume.

Summing up these results, one can say the following. In China, rapid economic growth spurred sudden GDP expansion centering on the southeastern coastal region. However, relative to the above regional economic indicators, change for railway freight volume was stagnant, with major cities like Beijing and Shanghai and regions like Dongbei (northeast) showing decrease. Especially in Heilongjiang, incoming volume showed an unusual $17 \%$ decrease from 1985 to 2003. In each province of the Dongbei region, growth in mainstay industries such as coal and steel has been centered on state-owned enterprises up to now. However, transportation volumes have decreased or stagnated. This is thought to reflect lagging response to conversion towards a modern industrial structure, and to production reforms of state-owned enterprises.

Another thing of note is that rail transport volume to and from major cities like Beijing and Shanghai is decreasing. In the backdrop of a growing network of expressways, this reflects the fact that the shipment of consumer goods to and from metropolitan areas is continuing to switch from rail transport to automobile shipment. 


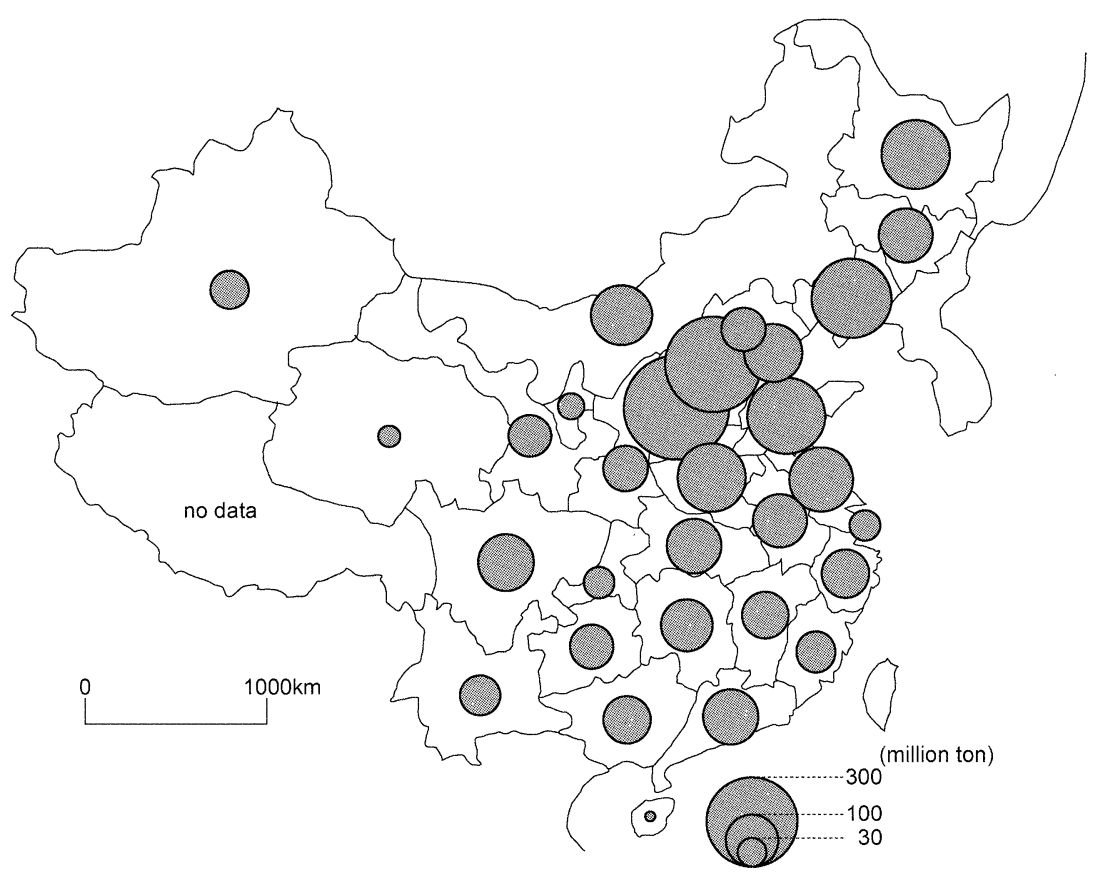

Figure 1. Railway freight transportation volume in each province, 2003.

Figures represent the total outgoing and incoming volume.

Source: Year Book of China Transportation and Communications 2004.

Table 1. Correlation analysis of economic indicators for each province in China (2003)

\begin{tabular}{llc}
\multicolumn{1}{c}{ Variable 1 } & \multicolumn{1}{c}{ Variable 2 } & Correlation index \\
\hline GDP total & Primary industry GDP & $0.769^{* *}$ \\
GDP total & Secondary industry GDP & $0.993^{* *}$ \\
GDP total & Tertiary industry GDP & $0.982^{* *}$ \\
Primary industry GDP & Secondary industry GDP & $0.725^{* *}$ \\
Primary industry GDP & Tertiary industry GDP & $0.683^{* *}$ \\
Secondary industry GDP & Tertiary industry GDP & $0.965^{* *}$ \\
Foreign capital investment & GDP total & $0.865^{* *}$ \\
Foreign capital investment & Primary industry GDP & $0.407^{*}$ \\
Foreign capital investment & Secondary industry GDP & $0.881^{* *}$ \\
Foreign capital investment & Tertiary industry GDP & $0.896^{* *}$ \\
Coal production & Railway freight shipping volume & $0.924^{* *}$ \\
Incoming railway freight volume & GDP total & $0.508^{* *}$ \\
Incoming railway freight volume & Primary industry GDP & $0.542^{* *}$ \\
Incoming railway freight volume & Secondary industry GDP & $0.502^{* *}$ \\
Incoming railway freight volume & Tertiary industry GDP & $0.456^{*}$ \\
\hline
\end{tabular}

** significance at 0.01 level

* significance at 0.05 level

Source: China statistical yearbook 2004 and Year book of China transportation and communications 2004.

Still, while struggling with the insufficient data they were able to obtain, Chinese transportation geographers Chen et al. (1993) pointed out that growth of distribution volume from economic development has primarily been supported by road transport in China since the 1980s. Also, in the north, economic development mainly depends on heavy industry products and raw materials, so there is large growth in transport tonnage. In contrast, economic growth in the south is pri- 


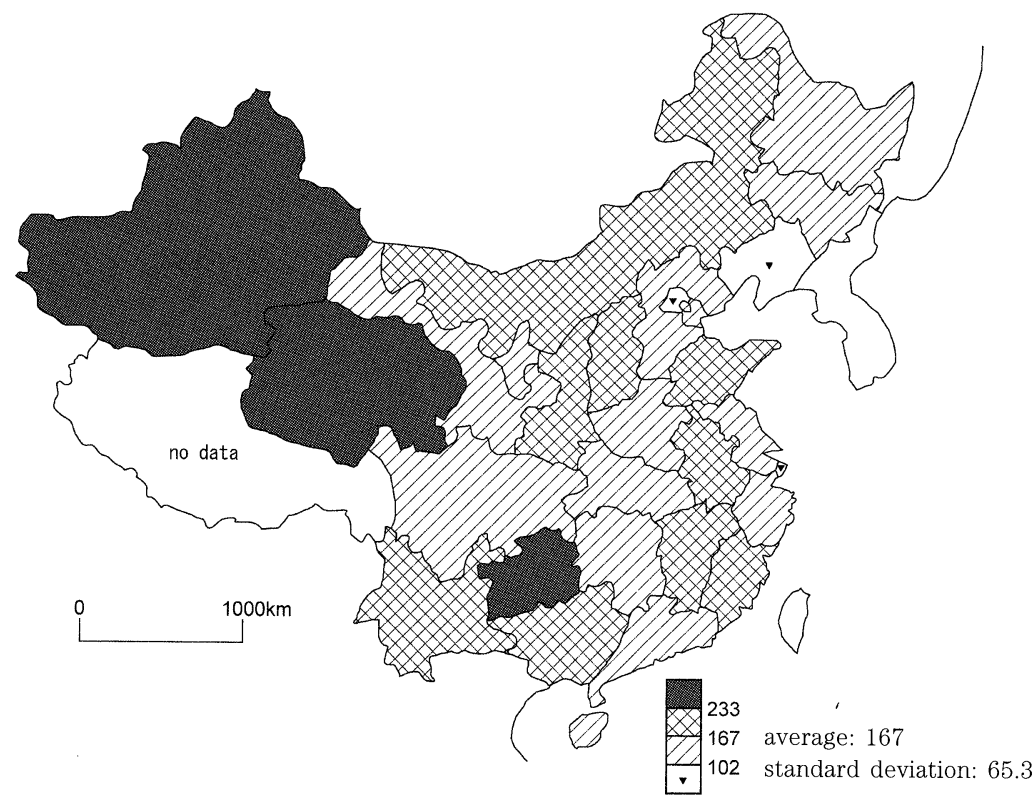

A. Indices of change of railway outgoing volume in each province from 1985 to 2003, setting 1985 figures as a baseline of 100

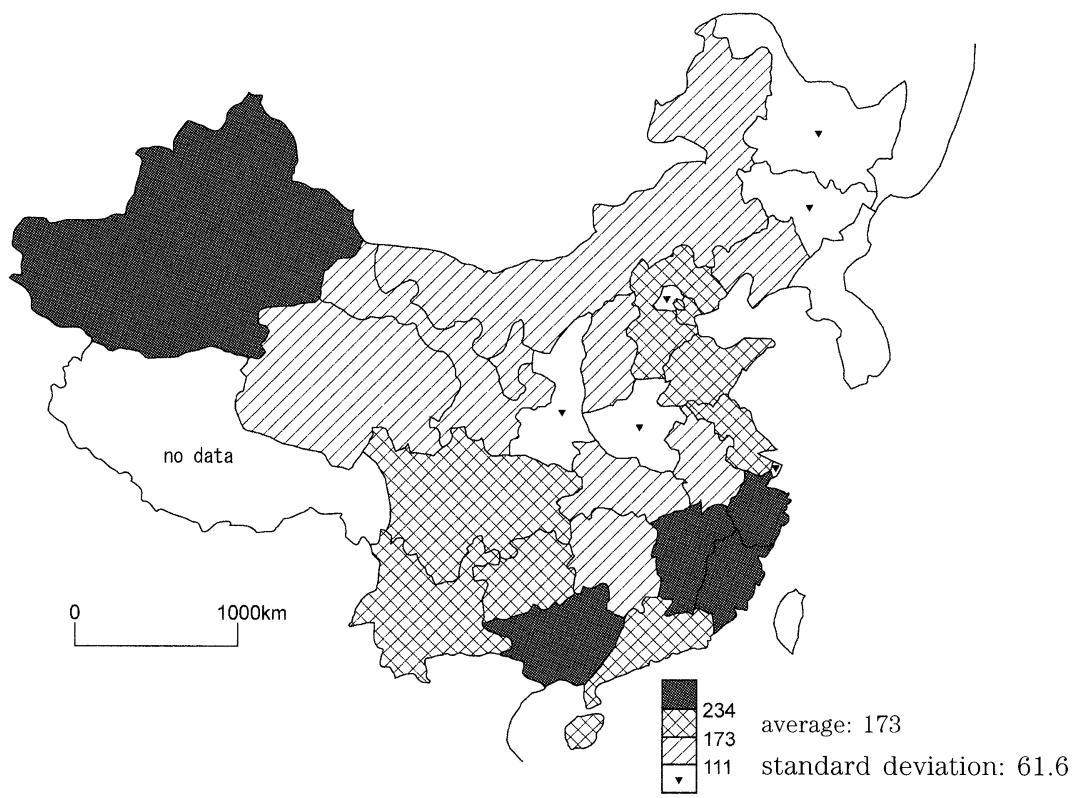

B. Indices of change of incoming railway freight volume in each province from 1985 to 2003 , setting 1985 figures as a baseline of 100

Figure 2. Changes from 1985 to 2003 in railway freight transportation volume in each province. Source: Year book of China transportation and communications. 
marily based on production of consumer goods and high added value products. Chen et al. (1993) indicate that these products have low weight and volume relative to their high value, so transport volume growth in the south is low relative to its level of economic development, compared to that in the north.

Here, we will compare the situation of freight transport in each transport mode, based on statistical data appearing in the China Statistical Yearbook (National Bureau of Statistics of China 2004). Table 2 shows the average freight transport distance for each transport mode. Looking at this, we see that in China, short haul transport mainly uses road transport, medium haul transport uses rail, and long haul transport uses waterways and civil aviation. Also, Table 3 shows the share of freight transport for each mode, by transport volume (tons) and ton-kilometers. Looking at this, road transport shows a high share of transport volume (tons), but railways and waterways show a high share of ton-kilometers. Table 4 shows changes in the transport volume (tons) and ton-kilometers of each mode, setting 1985 figures as a baseline of 1, and 2003 figures as a multiple of the 1985 level. For transport volume (tons) and ton-kilometers, we see that growth of road transport, waterways and civil aviation exceeded the growth of railways.

The analysis in this chapter identified a tendency for both production of resources and industrial development to be concentrated in spe-

Table 2. Average transport distance of freight in China $(\mathrm{km})$

\begin{tabular}{ccccccc}
\hline Year & Total & Railway & $\begin{array}{c}\text { Road } \\
\text { transport }\end{array}$ & Waterways & Pipelines & $\begin{array}{c}\text { Civil } \\
\text { aviation }\end{array}$ \\
\hline 1985 & 243 & 636 & 31 & 1,216 & 442 & 2,128 \\
2003 & 345 & 780 & 61 & 1,817 & 336 & 2,644 \\
\hline
\end{tabular}

Source: National Bureau of Statistics of China (2004).

Table 3. Share of freight volume by mode of transportation in China

Transport volume (tons)

\begin{tabular}{|c|c|c|c|c|c|c|}
\hline Year & Total & Railway & $\begin{array}{c}\text { Road } \\
\text { transport }\end{array}$ & Waterways & $\begin{array}{c}\text { Civil } \\
\text { aviation }\end{array}$ & Pipelines \\
\hline 1985 & 7,463 million tons & $17.51 \%$ & $72.10 \%$ & $8.48 \%$ & $0.00 \%$ & $1.83 \%$ \\
\hline 2003 & 15,614 million tons & $14.17 \%$ & $74.29 \%$ & $10.12 \%$ & $0.01 \%$ & $1.41 \%$ \\
\hline \multicolumn{7}{|c|}{ Freight ton-kilometers } \\
\hline Year & Total & Railway & $\begin{array}{c}\text { Road } \\
\text { transport }\end{array}$ & Waterways & $\begin{array}{c}\text { Civil } \\
\text { aviation }\end{array}$ & Pipelines \\
\hline 1985 & $1,836.53$ billion ton-kilometers & $44.24 \%$ & $10.36 \%$ & $42.09 \%$ & $0.02 \%$ & $3.28 \%$ \\
\hline 2003 & $5,385.89$ billion ton-kilometers & $32.02 \%$ & $13.18 \%$ & $53.32 \%$ & $0.01 \%$ & $1.37 \%$ \\
\hline
\end{tabular}

Source: National Bureau of Statistics of China (2004).

Table 4. The increase of freight transport in each mode in China from 1985 to 2003, setting 1985 figure as a baseline of 1

\begin{tabular}{lcccccc}
\hline \multicolumn{1}{c}{ Mode } & Total & Railways & $\begin{array}{c}\text { Road } \\
\text { transport }\end{array}$ & Waterways & $\begin{array}{c}\text { Civil } \\
\text { aviation }\end{array}$ & Pipelines \\
\hline Freight transport volume (tons) & 2.09 & 1.69 & 2.16 & 2.50 & 11.23 & 1.61 \\
Ton-kilometers & 2.93 & 2.12 & 3.73 & 3.73 & 13.95 & 1.22 \\
\hline
\end{tabular}

Source: National Bureau of Satistics of China (2004). 
cific regions of China, and the need to circulate resources and products throughout China's vast territory. The quantity of goods to be distributed is likely to increase rapidly in keeping with the pace of economic development. However, the increase in the volume of goods transported by rail has not been proportionately strong. In fact, it appears that the economically growing southeastern coastal region is separate from the regions where railway freight transport is prominent. Why would that be the case? It is thought that no strong correlation between various economic growth indicators and railway freight volume appears, because the economic development of China has been brought about by increased production of general consumer goods, and these goods are shipped by road or air. In the next chapter we examine the railway as an institution in China.

\section{Outline of China's Railway Freight Transport}

\section{Construction and development of the network}

Research by Leung (1980) uses techniques including network analysis and regression analysis to study the geographic and historical background of the construction of China's railway network. China had a deep desire for an integrated railway operation throughout the country, like those constructed before World War II by the United Kingdom, Germany, France, Russia, and Japan. Also, elimination of disparities between urban and rural areas and between central and peripheral regions was an important issue for China's socialist national construction. Thus development of the transport system was emphasized to utilize indigenous resources and strengthen self reliance. Railway construction was a part of this plan. Railways were originally a means for overcoming natural obstacles, for regional organization, and for raising efficiency of administrative control. They are a symbol of geopolitical integration, to unify the Han race and surrounding ethnic groups into one nation, centering on Beijing. The rail system was the most important means for military transport in wartime, and was designed to strengthen defenses around the national borders and territo- rial integration, and to eliminate China's internal regional disparities. This way of thinking led to the construction and opening of the Qingzang Railway in Tibet in 2006. However, Leung (1980) points out that since the 1970s, China's railway construction has come to emphasize economic over political goals, directing line expansion in populated regions more than expansion of lines to peripheral regions.

On the other hand, the American economic geographer Murphy (1956) cast doubt on China's railway construction policy. He pointed to China's poor transport condition as an obstacle to developing its domestic market and regional differentiation. Investment in railway construction becomes economical when transport volume is forecast to cover fixed costs. So, he criticized the actual investments in railway construction to strengthen unification with desert regions and connection to the Soviet Union near its inland national borders. Also, Ginsberg (1951) had already pointed out that road and air transportation is more desirable in thinly populated mountainous and remote regions, from the point of economic efficiency.

Research has also been done on the effects of railways on China's economic development and location of industries. Wu et al. (1967) noted that China's railway construction made large contributions to location of resource development and heavy and chemical industries in inland regions, and to the development of industrial cities. Liang (1982) came to the following conclusions regarding the impacts of China's railway construction on agriculture before World War II. Completion of railways encouraged higher agricultural productivity, by reducing the costs of transport and production. By improving access to major urban markets, the cultivation of cash crops by commercial management increased, to secure more stable and higher profits for farmers. However, development of commercial agriculture was limited to certain regions, due to the poor condition of the regionally limited railway network and road transport. Further, Lippit (1966) reported that starting with the 1960s, there was more emphasis on increase of food production and agricultural development, and the importance of roads over railways came to be recognized. This is because agricultural produc- 
tion is widely extended, transport volume of agricultural produce varies seasonally, and transport is in small lots, so truck transport has advantages over railways.

This primary emphasis on railways was greatly changed by the market liberalization policy of the mid 1980s. Since 1984, privatization of road and air transport and deregulation has been designed to increase new entries into the transport business. Construction and improvement of expressways and airports also progressed throughout the country. Thus competition intensified in the passenger sector between air, rail, and expressway buses. Divisions arose in the freight transport market, with resources, fuel, and raw materials via railways, water transport, and pipelines; durable consumer goods, daily necessities, and fresh food via road transport; electronic parts and high tech products via air ( $\mathrm{Ka}$ 2005).

How did the railways cope with harsh competitive conditions? According to the statistical document officially published by the China Railway Society and Statistical Center, Ministry of Railway (2003), Chinese Railway (1949-2001), until 2001 the total railroad distance was approximately $70,000 \mathrm{~km}$, about $25 \%$ of which was electrified, and about $33.3 \%$ had multiple trucks. However, there still remain many unelectrified and single track sections, even on major lines linking large metropolitan areas. Almost all steam locomotives have retired. For high speed passenger trains between large metropolitan areas, they are converting from a system with locomotives pulling passenger cars, to introduction of diesel motor unit trains and electronic motor unit trains. For freight transport, "five-fixed trains" are being operated to compete with road transport. These are freight trains with five specified conditions: (1) Specified operating schedule, (2) Specified transport lines, (3) Use of designated locomotives and freight cars, (4) Fixed transport travel time, (5) Fixed contact freight rates. These trains are used for transport of containers, fresh food, and small packages. Also, many freight cars are being steadily standardized on large 60 tons capacity cars.

As the most important issues for China's railways, the following 7 planning goals were publicly announced by the Ministry of Railway. (1)
Construct a wide area network extending throughout the entire country. (2) Construct a high speed passenger network. (3) Improve commuter transport between cities and suburbs. (4) Develop transport for bulky cargo. (5) Complete a high speed container train network throughout the country. (6) Promote international multi-modal transport, in other words container transportation in cooperation with foreign countries. (7) Establish a modern railway management system.

Furthermore, there were about $3,420,000$ railway employees in 1991, but through reform of the labor employment system since 1995, employment was switched to a contract system, and thus reduced to about 2, 480, 000 in 2001 (China Railway Society and Statistical Center, Ministry of Railway 2003:107).

As noted above, through market liberalization and deregulation since the mid-1980s, freight in China progressively switched from railway transport to trucks, and railway passengers switched to buses and airplanes. This is caused by the inability of railways to respond sufficiently to increased transport demand. Problems such as overstaffing, labor intensive practices, and deteriorated facilities and rolling stocks are thought to be causes of the low productivity of China railway operations. In other words, costs increased, and profitability and quality of services decreased. In short, it requires a long time to allocate and load freight cars. Train running speeds are low, and operating frequency is also low. In response, railway reform by the Chinese government introduced an "Economic Contract Responsibility System" in the Ministry of Railway, granting independence of authority, and enabling investment of external capital (Wu and Nash 2000).

Railway construction is by public investment by the central government, not through independent efforts of the Ministry of Railway. Thus there is insufficient analysis of costs and benefits, and it is easy for the irrationality of stateowned enterprise to appear. Moreover, railway enterprise profit and government budgets are invested in existing lines for electrification, laying parallel tracks, and introducing high speed trains, in addition to issuance of railway bonds. In this situation, the Chinese government is 
drafting reform proposals for the future, such as separation of functions of railway administration, construction, and management, in addition to splitting management of railways into five regions of the country (Ka 2005).

\section{Characteristics of transport items}

Table 5 shows the breakdown of major goods relative to overall freight transported by China's national railway in 2003, as published in the Year Book of China Transportation and Communications. From the table the following points become apparent. Certain products occupy a high percentage of freight transported by railnamely, energy resources like oil and coal, raw materials like iron ore, limestone, and sand and gravel, basic industrial materials like iron, steel, and chemicals, and agricultural products like grains (rice, wheat) and raw cotton. What these goods all have in common is that they tend to center on raw material goods or primary fuels or producer goods with low added value.

Most of these goods are not things that circulate freely in the market, but rather constitute nationally planned goods that, in accordance with central government plans, are produced and then distributed to sites of consumption. Under those national plans, large volumes of cargo are transported while taking into account the railroad carrying capacity, after which the railway transport route is selected and freight trains are set into motion. In particular, transport of basic raw materials for national land development such as coal, iron ore, steel, and cement was prioritized, along with chemical products for increased food production such as fertilizers and agricultural chemicals (Miao 1994).

At the same time, in response to this kind of trend, the national railway system has also witnessed a recent trend to introduce the abovementioned five-fixed trains; high-speed, smallpackage shipment trains, though the percentage relative to total freight is rather small. Given restrictions in the transport capacity of the national railway system, priority has been given to the shipment of nationally planned freight-that is, the shipment of raw fuels, raw materials, and producer goods. In other words, one could say that the railways have not had room to sufficiently accommodate the increase in consumer

Table 5. Transport volume and distance of major freight by China National Railway (2003)

\begin{tabular}{|c|c|c|c|c|c|}
\hline Freight types & $\begin{array}{c}\text { Transport } \\
\text { volume } \\
\text { (10000 tons) }\end{array}$ & $\begin{array}{l}\text { Transport } \\
\text { volume } \\
(\%)\end{array}$ & $\begin{array}{l}\text { Ton-kilometers } \\
\quad(1000000 \\
\text { ton-kilometers) }\end{array}$ & $\begin{array}{c}\text { Ton-kilometers } \\
(\%)\end{array}$ & $\begin{array}{c}\text { Average } \\
\text { transport } \\
\text { distance } \\
\text { (km) }\end{array}$ \\
\hline Coal & 88,132 & 44.3 & 505,540 & 31.0 & 574 \\
\hline Coke & 7,124 & 3.6 & 63,789 & 3.9 & 895 \\
\hline Petroleum & 10,765 & 5.4 & 102,934 & 6.3 & 956 \\
\hline Steel & 15,280 & 7.7 & 165,545 & 10.1 & 1,083 \\
\hline Ore & 18,082 & 9.1 & 103,868 & 6.4 & 574 \\
\hline Limestone & 7,945 & 4.0 & 50,799 & 3.1 & 639 \\
\hline Sand and gravel & 7,664 & 3.8 & 36,500 & 2.2 & 476 \\
\hline Cement & 3,652 & 1.8 & 15,347 & 0.9 & 420 \\
\hline Timber & 3,054 & 1.5 & 53,866 & 3.3 & 1,764 \\
\hline Chemical products & 5,660 & 2.8 & 72,312 & 4.4 & 1,278 \\
\hline Rice and wheat & 10,138 & 5.1 & 136,651 & 8.4 & 1,348 \\
\hline Cotton & 218 & 0.1 & 7,334 & 0.4 & 3,364 \\
\hline Salt & 1,263 & 0.6 & 10,031 & 0.6 & 794 \\
\hline Phosphate rock & 1,528 & 0.8 & 15,411 & 0.9 & 1,009 \\
\hline Parcels & 616 & 0.3 & 12,524 & 0.8 & 2,033 \\
\hline Containers-cargo & 5,907 & 3.0 & 92,148 & 5.6 & 1,560 \\
\hline Others & 12,048 & 6.0 & 187,742 & 11.5 & 1,558 \\
\hline Total & 199,076 & 100.0 & $1,632,341$ & 100.0 & 820 \\
\hline
\end{tabular}

Source: Year book of China transportation and communications 2004: 629. 
goods or small parcel goods accompanying high economic growth.

The national railway places a high priority on the transport of nationally planned freight composed of either important mainstay goods or strategic materials. Such shipments are relayed to one of dozens of switchyards distributed throughout the country and formed into freight trains (Zhang 1990). This work is performed using a computerized system, but for reasons of national defense, the shipment routes and freight train schedules are not published. Consequently, shippers cannot anticipate the arrival times of freight. And when an application is made for a rush shipment, it is also sometimes not possible to procure a freight car quickly. For that reason, railway transport is not fully suitable for shipping general consumer products.

Among the various forms of nationally planned freight, the one that is most highly prioritized and that can boast the most volume is coal. In 2003, coal accounted for nearly $45 \%$ of all freight volume carried by the national railway. As shown earlier in Table 1, a strong correlation was found between each region's coal production volume and railway freight outgoing volume. Further, by performing a simple regression analysis for each province between coal production volume and railway freight outgoing volume, the following significant result was obtained, as shown in Formula 1.

$$
\begin{aligned}
& Y=2257.104+1.019 X \\
& \quad\left(3.430^{* *}\right)\left(12.161^{* *}\right) \\
& Y \text { : railway freight outgoing volume by } \\
& \text { province (unit: } 10000 \text { tons) } \\
& X: \text { coal production volume by province } \\
& \quad \text { (unit: } 10000 \text { tons) } \\
& R^{2}=0.850 \\
& F=147.892^{* *} \\
& \text { Numerical values in parentheses are } t \text { val- } \\
& \text { ues. } \\
& * * \text { is significant at the } 0.01 \text { level. }
\end{aligned}
$$

From the above analysis, this regression model is significant overall, and it can be seen that there is a significant relationship between coal production volume in each province of China and total outgoing volume of freight from each province. In other words, the majority of outgo- ing railway freight in each province can be explained by coal production volume.

The Year Book of China Transportation and Communications compiles annual statistics on inter-province coal freight volume transported by rail. It is the only freight transport statistic published in China that specifies the article being transported. Looking specifically at provinces for which rail-based outgoing coal volume is high, we see that the largest volume is from Shanxi province in the Huabei region, followed closely by Shanxi's neighbors Neimengu and Hebei. In the Dongbei region, Heilongjiang and Liaoning predominate. Along the Changjiang River, the outgoing volume from Henan, Anhui, and Shandong is also large.

As shown in Table 5, in 2003, the average distance that coal was conveyed was $574 \mathrm{~km}$. Compared with other forms of cargo, that is not a particularly long distance. The reason for this is that rail transport is not used over extensive distances in China. In particular, in the Dongbei and Huabei regions, the coal is transported from coal mines to nearby shipping ports, and from there it is shipped by ocean to the southeastern coastal region.

The Railway Atlas of China, edited by Ministry of Railway (2004), gives outline diagrams of coal shipping routes via rail and sea. It describes shipping ports for coal as including Dalian, Qinhuangdao, Tianjin, Huanghua, Qingdao, Rizhao, and Lianyungang (see Figure 3). From these places, the coal is transported by sea to major consuming regions like Shanghai and Guangzhou. In other words, in the Dongbei region, coal from Heilongjiang, Jilin, and Liaoning is transported by rail to Dalian and then sent by sea to Shanghai. In the Huabei region, coal from Shanxi, Hebei, and Neimengu is sent to Qinhuangdao, Tianjin, Huanghua, Qingdao, and Rizhao ports by rail and then sent on by sea. In particular, the 652-km Daqin line connects directly from Datong in Shanxi and the port of Qinhuangdao in Hebei, and detours around Beijing's northern section. As a railway whose main purpose is to transport large volumes of coal, the line has been electrified and double-tracked. Furthermore, coal from Shaanxi is transported along the Longhai Line to Lianyungang in Jiangsu, where it is loaded onto ships. 


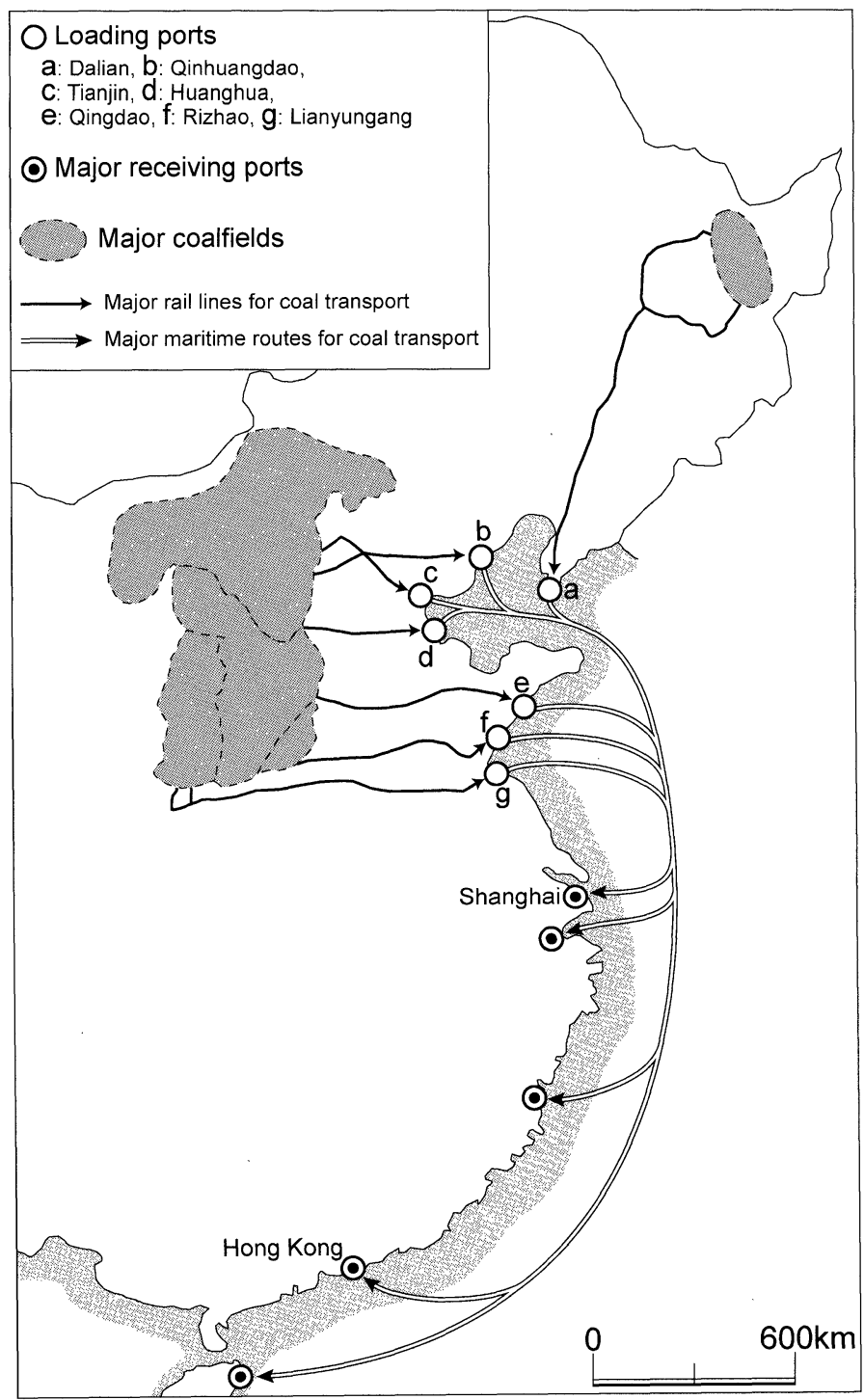

Figure 3. Major coal transportation routes in China. Source: Ministry of Railway, China (2004): 6-7.

Generally speaking, one can see an underlying trend whereby coal produced in the north of China is transported from west to east by rail, and then shipped by sea to large consuming regions in the southeastern coastal region. It is possible to avoid increasing the burden on the main railway lines running north to south. Another reason for choosing this approach is that it is less expensive to ship large quantities of goods over long distances by sea than by rail (Chen 1981; Todd 1996; Todd and Zhang 1994).

\section{Abstraction of Transport Zones}

Here, we want to review the analysis of railway freight transport zones in China from previous geography research. Zhang (1990) classified transport nodes in China according to their location and connecting functions between transport modes, and divided the entire country into 12 nodal regions, centering on major large scale nodes. Jin (1991) calculates a location quotient 
for transport volume between each province and agricultural and industrial production value, and along with comparing them, focuses on the destination outside the region receiving the highest volume of railroad freight, then divides the entire country into seven transport zones. Jin and Zhang (1991) calculate a "coefficient of intensity and range of inter-provincial transport linkage", based on the ratio of railroad freight transportation volume between provinces versus national freight transport volume. Looking at the changes of these figures over time, one can recognize a concentration of outgoing volume in places such as coal production areas, and dispersion of incoming volume among large consumption areas such as metropolitan areas. Based on the values of these coefficients, Jin and Zhang divide China into 4 transport zones: Dongbei (northeast), Huabei (north), Xibei (northwest), and central/south. Moreover, based on freight transport volume between each province, Rong et al. (1997) classifies all of China into six transport zones: Dongbei, Huabei, Huazong and Changjiang River Delta, Zhujiang River Delta, Xinan, Xibei.

Based on the above research results, we utilized multivariate analysis, and performed a detailed analysis of 2003 OD matrix data for national rail freight transport volumes between each province which appear in the Year Book of China Transportation and Communications. These statistics do not include Hong Kong or Macao. Also, as of 2003, the railway to Xizang (Tibet) was still under construction and had not yet begun operation, and so figures for it are not included in the analysis data. While it is true that freight is shipped by railway ferryboats to Hainan, the freight volume figures are extremely small. Accordingly, this analysis groups Hainan data together with that of neighboring Guangdong.

In this manner it is possible to tabulate OD matrix data for rail freight transport covering 28 provinces. The issue here is to show concisely the regional structure of China's rail freight transport by summarizing these data in some kind of appropriate form. From the OD matrix figures, one sees that overall intra-provincial transport volume and shipments between neighboring regions are high. From there, setting total outgoing rail freight volume from each province at $100 \%$, we calculated the destination freight for each province from one province.

As a result, the following three points can be made. First, for each province, the percentage of destination freight was greatest within the same province (the diagonal component of the OD matrix) from which it had been shipped. Second, destination volume was found to be mutually high between neighboring provinces. Third, destination volume from very distant provinces was low.

In other words, most outgoing freight was destined for either the same or a neighboring province. Nevertheless, given that Chinese provinces tend to be quite large, when transporting freight to a neighboring province or even within the same province, the distances involved tend to be rather considerable. Another way of saying this is that the percentage of rail freight volume that travels over the entire expanse of China is not large. By manipulating the characteristics of all this data it should be possible to identify rail freight transport zones.

Therefore, destination volume to nearby provinces from each other province showed high percentages. Using that fact, we applied a cluster analysis to the destination volume percentages from each province. By categorizing neighboring provinces within the same cluster, we thought it might be possible to abstract a transport zone.

Next, a cluster analysis was performed using the Ward method, based on the percentages of destination volumes from each province, with the 2003 figures for the total outgoing volumes from each province set at $100 \%$. The result, shown in Figure 4, is a dendrogram. Looking at the figure, one sees that China's rail freight transport can largely be divided into two major clusters, a northern region formed from the Huabei and Dongbei regions and a southern region made up of everything else.

Finally, as a result of the analysis the data was categorized into seven clusters. Figure 5 shows how the individual provinces group under these seven clusters, which constitute rail freight transport zones. The result of this is that China can be parsed into seven zones, a Dongbei (Northeast) zone, Huabei (North) zone, Huazhong (Central China)-Changjiang zone, 


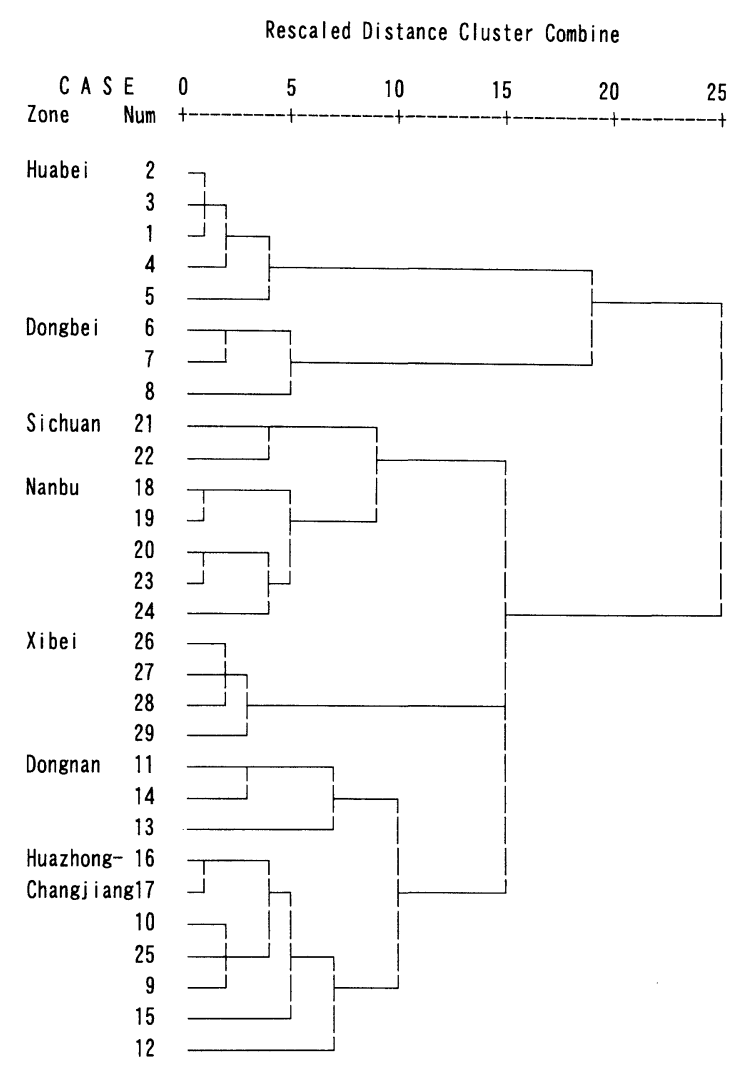

Figure 4. Dendrogram using Ward method cluster analysis.

Province numbers correspond to those in Figure 5 .

Huanan (South) zone, Xibei (Northwest) zone, Sichuan zone, Nambu (South) zone. However, these transport zones do not tend to reflect functional regions centering on major cities. Consequently, we do not see zones in which the departure and arrival of freight centers on large cities like Beijing or Shanghai.

As we have already seen in previous chapter, in China's rail freight transport, the large volume shipment has been taking place in specific sections of the country and comprising raw fuel and materials, including coal. This cluster analysis reflects the result that large volume transport appears in the form of data connecting between some provinces. This is something that must be taken into account.

For example, under China's traditional regional classification, Shaanxi is included under Xibei. However, coal from Shaanxi is transported in large amounts to Lianyungang in Jiangsu, adjacent to Shanghai. Reflecting these realities, Shaanxi should be classified into the HuazhongChangjiang zone, which includes Shanghai. In this way, vast regions-each of which straddles several provinces and reflects the existence of sections of the country characterized by the long-distance, large-volume transport of certain goods like coal-were brought together as definite and complete transport ranges within each cluster, and then abstracted in the form of transport zones.

Table 6 shows cross tabulations for mutual transport volume in 2003 for the seven rail freight transport zones. The data reveal that, out of the nearly 2 billion tons of outgoing volume for the entire national railway in 2003, the Huazhong-Changjiang zone accounted for $26.6 \%$, the Huabei zone for $26.0 \%$, and the Dongbei zone for $17.1 \%$. Moreover, out of the roughly 2 billion tons of total incoming volume, the Huabei zone accounted for $33.2 \%$, the Huazhong-Changjiang zone for $24.2 \%$, and the Dongbei zone for $16.6 \%$. Whether for incoming or outgoing freight, these three major transport zones comprised a high percentage of total freight.

Of these figures, Huabei's intra-zonal transport accounted for $21.3 \%$, Dongbei's for $13.3 \%$, and Huazhong-Changjiang's for $15.6 \%$. Thus, the intra-zonal freight volume for these major transport zones is overwhelmingly large. This shows that a large proportion of transport takes place entirely within these transport zones. And from that fact, it is possible to regard each of these transport zones as a fixed, independent rail transport sphere. Transport from the Huabei zone to the Huazhong-Changiiang zone accounts for $6.9 \%$ of the total, though transport in the opposite direction is a mere $2.0 \%$. We may presume that this reflects the fact that coal is transported from Huabei, a coal-producing region, to Huazhong, a major nexus for the chemical industry.

These figures seem to indicate that China's rail freight transport does not show distance-decay effects centering on capitals and other major cities of each province. Instead, the ranges covering areas between each neighboring province are found by cluster analysis, including all large volume transport routes for specific goods. Most 


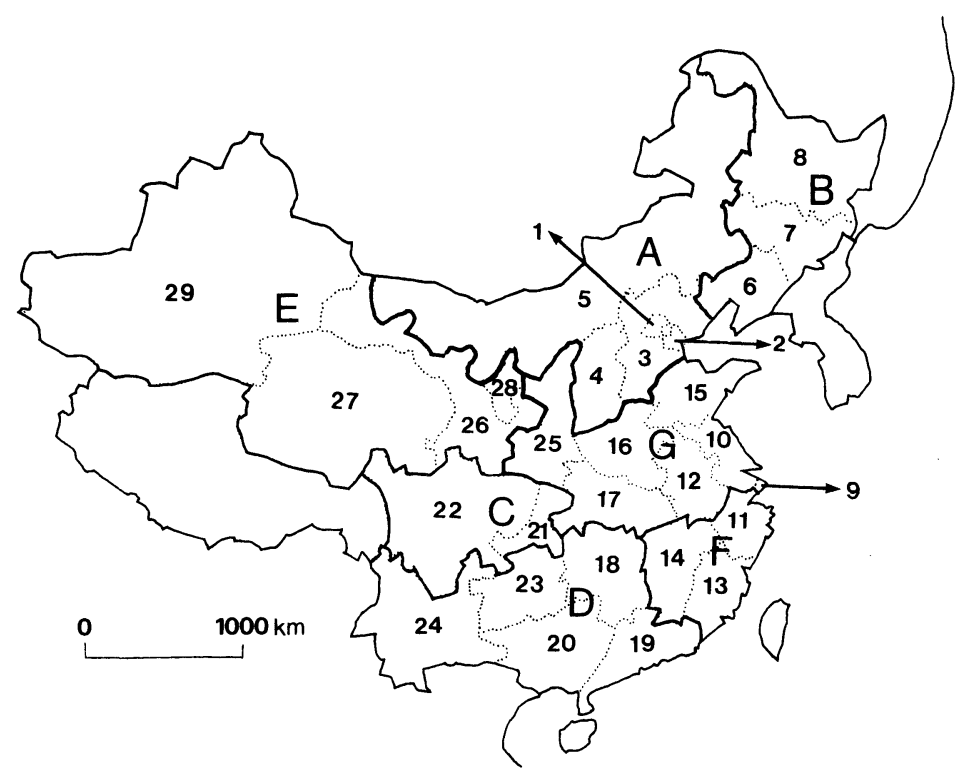

Figure 5. Railway freight transport zones extracted from the dendrogram in Figure 4.

A: Huabei zone, B: Dongbei zone, C: Sichuan zone, D: Nanbu zone,

E: Xibei zone, F: Dongnan zone, G: Huazhong-Changjiang zone

Province numbers correspond to those in Figure.4.

Table 6. Percentages of freight transport volume by rail between abstracted transport zones (2003)

\begin{tabular}{|c|c|c|c|c|c|c|c|c|}
\hline \multirow[b]{2}{*}{ Origin } & \multicolumn{7}{|c|}{ Destination } & \multirow[b]{2}{*}{ Total } \\
\hline & $\begin{array}{l}\text { Huabei } \\
\text { zone }\end{array}$ & $\begin{array}{l}\text { Dongbei } \\
\text { zone }\end{array}$ & $\begin{array}{l}\text { Schuan } \\
\text { zone }\end{array}$ & $\begin{array}{l}\text { Nanbu } \\
\text { zone }\end{array}$ & $\begin{array}{l}\text { Xibei } \\
\text { zone }\end{array}$ & $\begin{array}{l}\text { Dongnan } \\
\text { zone }\end{array}$ & $\begin{array}{c}\text { Huazhong- } \\
\text { Changjiang } \\
\text { zone }\end{array}$ & \\
\hline Huabei zone & 21.30 & 2.88 & 0.28 & 0.72 & 0.42 & 0.75 & 6.86 & 33.21 \\
\hline Dongbei zone & 1.66 & 13.27 & 0.15 & 0.21 & 0.11 & 0.13 & 1.07 & 16.60 \\
\hline Sichuan zone & 0.14 & 0.07 & 2.41 & 0.88 & 0.11 & 0.13 & 0.62 & 4.36 \\
\hline Nanbu zone & 0.31 & 0.14 & 0.95 & 7.79 & 0.15 & 0.93 & 0.90 & 11.17 \\
\hline Xibei zone & 0.51 & 0.11 & 0.36 & 0.24 & 3.18 & 0.13 & 1.03 & 5.56 \\
\hline Dongnan zone & 0.10 & 0.09 & 0.13 & 0.86 & 0.07 & 3.19 & 0.52 & 4.96 \\
\hline $\begin{array}{l}\text { Huazhong-Changjiang } \\
\text { zone }\end{array}$ & 2.02 & 0.56 & 0.75 & 2.09 & 0.43 & 2.73 & 15.57 & 24.15 \\
\hline Total & 26.04 & 17.12 & 5.03 & 12.79 & 4.47 & 7.99 & 26.57 & 100.00 \\
\hline
\end{tabular}

transport terminates within the transport zones based on clusters found. This reflects the fact that within the huge transport zones found, long haul large volume transport of coal and other items is recognized, and figures for transport distance within each single transport zone are certainly not small. This serves to disturb distancedecay effects, so even if we apply a spatial interaction model to China's rail freight transport zone, it can reduce the model's compatibility. In other words, large volume of freight are transported under the national plan, especially coal, and it is natural to carry out transport between production areas and consumption areas in a way that reduces cross-hauling, so it seems obvious that transport volume within same transport zone is larger. 


\section{Conclusion}

As a result of the foregoing analysis of China's rail freight transport, it has become clear that huge amounts of coal are being shipped, and that besides the economically growing southeastern coastal regions, the Huabei and Dongbei zones are responsible for large volumes of both arriving and departing freight. In other words, rail freight transport is not centered on large metropolitan areas and industrial areas, but on the specialized large-volume shipment of specific goods in specific sections of the country, such as between coal-producing areas and certain ports. We performed a cluster analysis by taking the distribution ratios to destination provinces from each province, and were thereby able to abstract seven transport zones.

China's rail freight transport centers on largevolume shipments in certain sectors of the country. The items shipped tend to be raw fuels like oil, coal, and iron ore as well as raw materials like iron and steel products or cement. Such rail transport tendencies mean that the system is unable to sufficiently accommodate the demand to ship small-parcel, high-frequency shipments of the consumer goods that have blossomed with China's recent economic development. Such goods have instead come to be transported via air freight or via private road-haulers that have been allowed to participate in the market, thanks to deregulation. Together with the provision of expressways, these shipment means are posing a considerable challenge to the railways.

Further, the large-volume transport of coal and oil by rail can be expected to change, as thanks to the revolution in energy usage, coal will be gradually replaced by oil and other energy fuels. The large-scale shipments of raw fuels and materials also take place along the Changjiang River and via coastal maritime transport. Moreover, China's long-distance pipeline transportation network for oil and natural gas has expanded considerably. As shown in the second chapter, we can presume that since outgoing and incoming rail shipments from and to Heilongjiang have decreased markedly, oil is increasingly being transported over pipelines instead of by rail (Ren 1995).
With the permeation of the market economy in China, even in old-style managed enterprises that center on raw-materials type industries, a switch to the production of high added-value products and capital-intensive goods, namely a change in production structure, is certainly underway. In the process, the center of gravity of goods distribution is likely to continue to move away from the large-scale transport of raw materials centered on railways towards high-frequency, small-parcel shipments of consumer goods distributed by road.

China's railways suffer from various problems as described above. To resolve these issues, it will be necessary to determine the kind of role railways should play in the future within a comprehensive transportation policy. To that end, statistics that compare the various means of transport, and that pinpoint which system was used to distribute various goods and articles, are required. Once these are made public, more refined research studies will at last become possible.

(Received 15 December 2006)

(Accepted 30 July 2007)

\section{References}

Berry, B. J. L. 1966. Essays on commodity flows and the spatial structure of the Indian economy. Department of Geography Research Paper No. 111. Illinois: University of Chicago.

Chen, H. 1981. Regional patterns of coal transportation. Economic Geography (Jingi Dili) 3(3): 27-40. (C)

Chen, H., Zhang, W. C., and Jin, F. G. 1993. Transportation geography of China. Beijing: Science Publisher. (C)

China Railway Society and Statistical Center, Ministry of Railway. 2003. Chinese railways (1949-2001). Beijing: China Railway Publisher. (CE)

Démurger, S. 2001. Infrastructure development and economic growth: An explanation for regional disparities in China? Journal of Comparative Economics 29: 95-117.

Démurger, S., Saches, J. D., Woo, W. T., Bao, S., Chang, G., and Mellinger, A. 2001. Geography, economic policy and regional development in China. Harvard Institute of Economic Research Paper No. 1950. Massachusetts: Harvard University.

Fan, C. C. 1995. Of belts and ladders: State policy and uneven development in Post-Mao China. Annals 
of the Association of American Geographers 85: 421-449.

Fan, C. C., and Scott, A. J. 2003. Industrial agglomeration and development: A survey of spatial economic issues in East Asia and a statistical analysis of China. Economic Geography 79: 295-319.

Ginsberg, N. S. 1951. China's railroad network. Geographical Review 41: 470-474.

Han, J.S. 1981. Regional structure of freight flow by rail in Korea. Annals of Tohoku Geographical Association 33: 22-34. (JE)

Hoyle, B., Leinbach, T., Smith, J., and Spencer, A. 1998. The role of transport in the development process: Case studies from Quebec, Indonesia, Zimbabwe and China. In Modern transport geography second edition, ed. B. Hoyle and R. Knowles, 41-74. Chichester: John Wiley \& Sons.

Jin, F. G. 1991. Experimental research on spatial transportation linkage in China: An example of freight transportation. Acta Geographica Sinica 46(1): 16-25. (CE)

Jin, F. G. and Zhang, W. C. 1991. Research on interprovincial transport linkage in railway freight system. Scientia Geographica Sinica 11(1): 19-28. (CE)

Ka, R. 2005. Economic growth and development of transport infrastructures in China. In Circulation of modern China, ed. H. Matsue, 29-51. Tokyo: Dobunkan Syuppan. (J)

Kanno, M. 1976. Canonical analysis of commodity flows and socio-economic structure in major US metropolitan areas. Geographical Review of Japan 49: $197-216$.

Knudsen, D. C. 1985. Exploring flow system change: US rail freight flows, 1972-1981. Annals of the Association of American Geographers 75: 539551.

Leung, C. K. 1980. China: Railway patterns and national goals. Department of Geography Research Paper No. 195. Illinois: University of Chicago.

Liang, E. P. 1982. China: Railways and agricultural development 1875-1935. Department of Geography Research Paper No. 203. Illinois: University of Chicago.

Lippit, V. D. 1966. Development of transportation in Communist China. The China Quarterly 27: 101119.

Miao, Q. L. 1994. Railway transportation in China. Beijing: China Railway Publisher. (C)

Ministry of Railway, China. 2002. China railway yearbook 2002. Beijing: Ministry of Railway, China. (C)

Ministry of Railway, China. 2004. Railway atlas of China. Beijing: China Railway Publisher. (C)
Mitsuhashi, S. 1978. Japanese commodity flows. Department of Geography Research Paper No. 187. Illinois: University of Chicago.

Murayama, Y. 1984. Regional structure of Japanese commodity flows, an approach of general field theory. Annals of the Association of Economic Geographers (Keizai Chirigaku Nenpo) 30: 95111. (JE)

Murayama, Y. 1990. Regional structure of commodity flows in Japan: An application of dynamic geographical field theory. Science Reports of the Institute of Geoscience, The University of Tsukuba, section A 11: 79-114.

Murphy, R. 1956. China's transport problem and communist planning. Economic Geography 32: 1728.

National Bureau of Statistics of China. 2004. China Statistical Yearbook 2004. Beijing: China Statistics Press. (CE)

Ren, X. Z. 1995. The present situation and history of petroleum distribution in China. In Circulation system of production materials in China, ed. T. Harada, 25-45. Tokyo: Asian Economic Institute. (J)

Rong, C. H., Li, W. Y., Linge, G., and Forbes, D. 1997. Linking the regions: A continuing challenge. In China's new spatial economy: Heading towards 2020, ed. G. Linge, 46-71. Oxford: Oxford University Press.

Starr, Jr., J. T. 1976. The evolution of the unit train, 1960-1969. Department of Geography Research Paper No. 158. Illinois: University of Chicago.

Todd, D. 1996. North-south energy resource transfers in China and the port intermediary. Tijdschrift voor Economische en Sociale Geografie 87: 195208.

Todd, D., and Zhang, L. 1994. Ports and coal transfer: Hub of China's energy supply policy. Energy Policy 22: 609-622.

Ullman, E. L. 1957. American commodity flow: A geographical interpretation of rail and water traffic based on principles of spatial interchange. Seattle: University of Washington Press.

Wallace, E. R. 1967. Areal interaction in India: Commodity flows of the Bengal-Behar industrial area. Department of Geography Research Paper No. 110. Illinois: University of Chicago.

Wu, J. H. and Nash, C. 2000. Railway reform in China. Transport Review 20: 25-48.

Wu, Y. L., Ling, H. C., and Wu, G. H. 1967. The spatial economy of Communist China. New York: Frederick A. Praeger.

Yang, D. 1990. Patterns of China's regional development strategy. The China Quarterly 122: 
230-257.

Year Book House of China Transportation and Communications 2004. Year Book of China Transportation and Communications 2004. Beijing: Year Book House of China Transportation and Communications. (C)

Zhang, W. C. 1990. Location of nodes on transport net- works and regional structures in China. Economic Geography (Jingi Dili) 10(4): 55-62. (C)

$(J)$ : written in Japanese

(JE): written in Japanese with English abstract

(C): written in Chinese

(CE): written in Chinese with English abstract 